\title{
Identification of vegetative proteins for a two- dimensional protein index of Bacillus subtilis
}

\author{
Roland Schmid, Jörg Bernhardt, ${ }^{2}$ Haike Antelmann, ${ }^{2}$ Andrea Völker, ${ }^{2}$ \\ Hiltraut Mach, ${ }^{2}$ Uwe Volker ${ }^{2}$ and Michael Hecker ${ }^{2}$
}

Author for correspondence: Michael Hecker. Tel: +493834 864201. Fax: +493834864202.

e-mail: hecker@microbio7.biologie.uni-greifswald.de

\footnotetext{
1 Universität Osnabrück, Abteilung für Mikrobiologie, 49076 Osnabrück, Germany

2 Institut für Mikrobiologie und Molekularbiologie, Ernst-Moritz-ArndtUniversität Greifswald, 17487 Greifswald, Friedrich-Ludwig-JahnStraße 15, Germany
}

\begin{abstract}
Twenty-three of the most prominent spots which are visible on twodimensional (2-D) protein gels of Bacillus subtilis crude extracts were selected as marker spots for the construction of a 2-D protein index. $\mathbf{N}$-terminal sequencing of the corresponding proteins resulted in the identification of enzymes involved in glycolysis, TCA cycle, pentose phosphate cycle, amino acid metabolism, nucleotide biosynthesis and translation. Using computer analysis of the 2-D protein gels, most of these metabolic enzymes were found to be synthesized at a reduced rate after different stresses and glucose starvation. Such an approach permits a rapid and global evaluation of the regulation of different branches of metabolism in response to various physiological conditions.
\end{abstract}

Keywords: two-dimensional protein index, glucose limitation, heat shock, salt stress, vegetative proteins, glycolytic enzymes

\section{INTRODUCTION}

At present there is a strong impetus to explore the complete genomes of prokaryotic and eukaryotic organisms. Besides the human genome project, work is being carried out to determine the complete sequences of Escherichia coli, Bacillus subtilis (Kunst \& Devine, 1991; Devine, 1995), Arabidopsis thaliana, Mus musculus, Drosophila melanogaster and Caenorhabiditis elegans. The complete sequences of the genomes of Haemophilus influenzae (Fleischmann et al., 1995) and Mycoplasma genitalium (Fraser et al., 1995) have been reported. B. subtilis is included in the list of organisms to be sequenced because it is considered to be a model system for Gram-positive bacteria, it has the ability to undergo spatial and temporal differentiation, and has industrial importance.

Five European laboratories started the systematic sequencing of B. subtilis in September 1988. Now about 20 groups are working world-wide on this project. However, the sequencing itself is only the first step in the elucidation of the function of the individual genes and the proteins encoded. Genome sequencing is therefore generally accompanied by research programmes designed to characterize the function of each single gene as well as to understand the regulation of those genes. High resolution two-dimensional (2-D) protein gel electro-

Abbreviation: 2-D, two-dimensional phoresis of $\mathrm{L}-\left[{ }^{35} \mathrm{~S}\right]$ methionine-labelled protein extracts is a very potent tool for the investigation of complex changes in gene expression. Using this technique more than 500 proteins can be separated and their synthesis rates under quite different environmental conditions can be monitored. The technique is even more powerful if the stained 2-D protein gels or autoradiograms of the gels are analysed with sophisticated computer program packages which permit the simultaneous analysis of either the synthesis rate or the quantity of a large number of proteins. The proteins can then be identified by microsequencing of the protein spots. Such an approach will provide essential information on gene regulation and the function of the proteins.

For E. coli a very extensive protein database, Eco2Dbase, has been constructed by F. C. Neidhardt and R. A. VanBogelen (VanBogelen et al., 1992) that incorporates data on gene regulation as well as on the function of $E$. coli proteins. Very detailed databases of 2-D protein separations have also been established with different determinations for human body fluids (PDD, Merril et al., 1995; Lemkin et al., 1995), human liver (Hughes et al., 1993), plasma and red blood cells (Golaz et al., 1993), human heart (Corbett et al., 1994) and Saccharomyces cerevisiae (YPD, Garrels et al., 1995).

Here we present the beginning of the construction of a protein index for $B$. subtilis. A master gel of exponentially growing cells is shown, where the identity of 23 vegetative protein spots has been determined by $\mathrm{N}$ - 


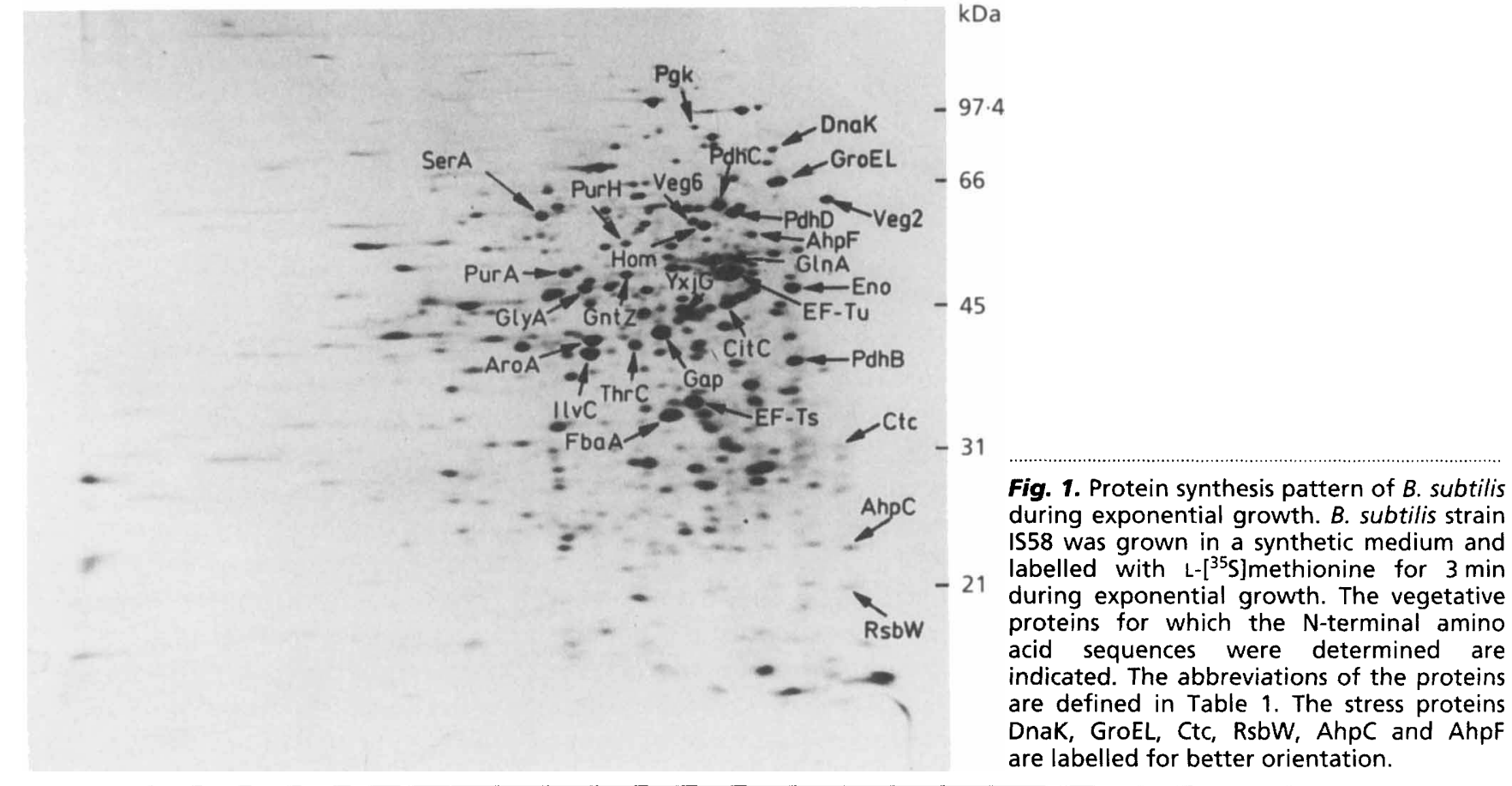

terminal microsequencing or determination of internal sequences. We are publishing these results at this stage to make reference points available for other groups employing 2-D protein gel electrophoresis for the investigation of $B$. subtilis. The synthesis pattern of these presumably vegetative proteins during exponential growth, heat shock, salt stress and glucose starvation is compared.

\section{METHODS}

Bacterial strain and culture conditions. All experiments were performed with B. subtilis IS58 (trpC2 lys3) (Smith et al., 1980) grown at $37^{\circ} \mathrm{C}$ under vigorous agitation in a synthetic medium described previously (Stülke et al., 1993). Glucose starvation was triggered by cultivating the bacteria in medium containing the growth-limiting concentration of $0.05 \%$ glucose. Heat shock was accomplished by transferring the culture from $37^{\circ} \mathrm{C}$ to $48^{\circ} \mathrm{C}$ and salt stress was induced by adding sodium chloride to a final concentration of $4 \%$.

Pulse labelling and analytical 2-D gel electrophoresis. For preparation of an analytical gel showing the typical vegetative protein pattern under optimal growth conditions, $2 \mathrm{ml}$ bacterial culture was labelled at an $\mathrm{OD}_{500}$ of 0.4 with $5 \mu \mathrm{Ci}$ $(185 \mathrm{kBq})$ L- $\left[{ }^{35} \mathrm{~S}\right]$ methionine $(\mathrm{ml} \text { culture })^{-1}$ for $3 \mathrm{~min}$. For analysis of changes in the protein synthesis pattern during glucose starvation or stress, bacteria were labelled at different times after the onset of the stationary phase or after the imposition of stress. L- $\left[{ }^{35} \mathrm{~S}\right]$ Methionine incorporation and protein synthesis were stopped by adding $100 \mu \mathrm{g}$ chloramphenicol m/ $\mathrm{m}^{-1}$ and an excess of cold methionine $(1 \mathrm{mM})$ as well as by transferring the culture onto ice. Cells were harvested by centrifugation $\left(4^{\circ} \mathrm{C}, 10000\right.$ r.p.m., $\left.10 \mathrm{~min}\right)$, washed twice with TE buffer ( $0.1 \mathrm{M}$ Tris/HCl, $1 \mathrm{mM}$ EDTA, $\mathrm{pH} 7.5$ ) and the pellet was resuspended in $400 \mu \mathrm{l}$ sonication buffer (10 mM Tris/ $\mathrm{HCl}, \mathrm{pH} 7 \cdot 5,5 \mathrm{mM} \mathrm{MgCl}_{2}, 2 \mathrm{mM}$ PMSF).
Cells were disrupted by ultrasonication (Labsonic, $5 \mathrm{~mm}$ probe, $60 \mathrm{~W}, 3 \times 2 \mathrm{~min}$ ) on ice and the cell debris was removed by centrifugation. The radioactivity incorporated was determined by liquid scintillation counting. Crude protein extracts were dried in a SpeedVac and the pellet was resuspended in sample buffer $(2 \%$ Servalyte pH $3-10,9 \mathrm{M}$ urea, $4 \%$ CHAPS, $100 \mathrm{mM}$ DTT, $2 \mathrm{mM}$ PMSF). For isoelectric focusing, a gel solution was prepared using $16.5 \mathrm{~g}$ urea, $4.02 \mathrm{ml} 30 \%$ Acrylamide/Bisacrylamide $(28 \cdot 4: 1 \cdot 6), 6 \mathrm{ml}$ $10 \%$ Nonidet-P40, $1.2 \mathrm{ml} 40 \%$ Servalyte $\mathrm{pH} 5-7,0.3 \mathrm{ml}$ $40 \%$ Servalyte $\mathrm{pH} 3.5-10,5.91 \mathrm{ml}$ aqua bidest, $45 \mu 110 \%$ ammonium persulfate and $30 \mu \mathrm{l} N, N, N^{\prime}, N^{\prime}$-tetramethylethylenediamine (TEMED). Gels were cast in 14-cm-long tubes $(4 \mathrm{~mm}$ i.d.) and overlaid with $9 \cdot 5 \mathrm{M}$ urea. After gel polymerization, urea was removed and samples containing $10^{6}$ c.p.m. were loaded and overlaid with sample overlay buffer $(0.5 \mathrm{M}$ urea, $50 \mathrm{mM}$ DTT, $0.02 \%$ Nonidet-P40, $0.1 \%$ Servalyte pH 3.5-10). Samples were focused for $15 \mathrm{~h}$ at $400 \mathrm{~V}$ and for an additional hour at $600 \mathrm{~V}$ using the PROTEAN II xi cell from Bio-Rad.

After equilibration in equilibration buffer $\quad 62.5 \mathrm{mM}$ Tris $/ \mathrm{HCl}, \mathrm{pH} 6.8 ; 3 \%$ SDS, $10 \%$ glycerol, $50 \mathrm{mM}$ DTT, $0.01 \%$ Bromophenol Blue) for $15 \mathrm{~min}$, the isoelectric focusing gels were embedded in $50 \mathrm{mM} \mathrm{DTT} / 1 \%$ agarose onto nonlinear gradient (10-20\%) SDS-polyacrylamide gels and run at a constant power of $8 \mathrm{~mA}$ per gel. After running the gels were fixed in $50 \%$ methanol $/ 8 \%$ acetic acid and dried.

Preparative 2-D gel electrophoresis and N-terminal microsequencing. For preparative 2-D protein gel electrophoresis, $500 \mu \mathrm{g}$ of the crude protein extract was separated using the 2D Electrophoresis System from Millipore. N-terminal microsequencing of proteins was carried out as described previously (Völker et al., 1994) with modifications according to Antelmann et al. (1995). Briefly, the Coomassie-stained protein spots were cut from the preparative 2-D gels, concentrated according to the protocol of Rider et al. (1995), 
Table 1. Summary of the vegetative proteins characterized in this investigation

\begin{tabular}{|c|c|c|c|c|c|c|c|}
\hline \multirow[t]{2}{*}{ Protein } & \multirow[t]{2}{*}{ Function } & \multirow[t]{2}{*}{ N-terminal sequence* } & \multicolumn{2}{|c|}{ Estimated from gel } & \multicolumn{2}{|c|}{$\begin{array}{l}\text { Calculated from } \dagger \\
\text { sequence }\end{array}$} & \multirow[t]{2}{*}{ Accession no. } \\
\hline & & & $\begin{array}{c}\text { Size } \\
(\mathrm{kDa}) \neq\end{array}$ & pI $\$$ & $\begin{array}{c}\text { Size } \\
(\mathrm{kDa})\end{array}$ & pI & \\
\hline \multicolumn{8}{|c|}{$\begin{array}{l}\text { Amino acid } \\
\text { metabolism }\end{array}$} \\
\hline AroA & $\begin{array}{l}\text { 2-Dehydro-3-deoxyphosphoheptonate } \\
\text { aldolase (EC 4.1.2.15) } \\
\text { Chorismate mutase (EC } 5.4 .99 .5 \text { ) }\end{array}$ & SNTELELLRQ KADELNLQIL KLIN & 39 & $5 \cdot 7$ & $39 \cdot 5$ & $5 \cdot 5$ & p39912 \\
\hline $\mathrm{G} \ln A$ & Glutamine synthetase (EC 6.3.1.2) & MAKYTREDIE KLVKEENVKY IRL & 48 & $5 \cdot 4$ & $50 \cdot 1$ & 5.0 & p12425 \\
\hline GlyA & $\begin{array}{l}\text { Glycine hydroxymethyltransferase } \\
\text { (EC 2.1.2.1) }\end{array}$ & MKHLPAQDEQ VFNAIKNERE & 47 & $5 \cdot 7$ & $45 \cdot 5$ & $5 \cdot 6$ & p39148 \\
\hline Hom & $\begin{array}{l}\text { Homoserine dehydrogenase } \\
\text { (EC 1.1.1.3) }\end{array}$ & MKAIRVGLLG LGTVGSGV & 56 & $5 \cdot 4$ & $47 \cdot 5$ & $5 \cdot 1$ & p19582 \\
\hline IlvC & $\begin{array}{l}\text { Ketol-acid reductoisomerase } \\
(\mathrm{EC} 1.1 .1 .86)\end{array}$ & VKVYYNGDIK ENVLAGKTVA V & 38 & $5 \cdot 7$ & $37 \cdot 5$ & $5 \cdot 5$ & p 37253 \\
\hline SerA & $\begin{array}{l}\text { Phosphoglycerate dehydrogenase } \\
\text { (EC } 1.1 .1 .95 \text { ) }\end{array}$ & MFRVLVSDKM XNDGL & 42 & $5 \cdot 9$ & $45 \cdot 6$ & $6 \cdot 3$ & p35136 \\
\hline ThrC & Threonine synthase (EC 4.2.99.2) & MXKGLIHQYK EFLPVTDQ & 39 & $5 \cdot 6$ & 37.5 & $5 \cdot 3$ & p04990 \\
\hline \multicolumn{8}{|c|}{ Glycolysis } \\
\hline Eno & Enolase (EC 4.2.1.11) & PYIVDVYARE VLDSRGNPTV EVGE & 45 & $5 \cdot 1$ & $46 \cdot 6$ & $4 \cdot 5$ & p37869 \\
\hline FbaA & $\begin{array}{l}\text { Fructose-bisphosphate aldolase } \\
\text { (EC } 4.1 .2 .13)\end{array}$ & PLVSMTEMLN TAKE & 32 & $5 \cdot 5$ & $30 \cdot 4$ & $5 \cdot 2$ & $\mathrm{p} 13243$ \\
\hline \multirow[t]{2}{*}{ Pgk } & Phosphoglycerate kinase & MNKKTLKDID VKGKVVFXRV DFN & 80 & $5 \cdot 4$ & $\mathrm{NA}$ & & p40924 \\
\hline & $\begin{array}{c}\mathrm{N} \text { terminus alignment to: } B \text {. megaterium } \\
\text { B. stearothermopbilus }\end{array}$ & $\begin{array}{l}\text { MNKKTLKDID VKGKRVFCRV DFN } \\
\text { MNKKTIRDVD VRGKRVFCRV DFN }\end{array}$ & & & & & \\
\hline Gap & $\begin{array}{l}\text { Glyceraldehyde-3-phosphate } \\
\text { dehydrogenase (EC 1.2.1.12) }\end{array}$ & AVKVGINGFG RIG & 44 & $5 \cdot 5$ & $35 \cdot 7$ & $5 \cdot 2$ & p09124 \\
\hline PdhB & $\begin{array}{l}\text { Pyruvate dehydrogenase (E1 } \\
\text { component) } \beta \text { subunit (EC 1.2.4.1) }\end{array}$ & AQMTMIQAIT DALRTELKN & 38 & $5 \cdot 1$ & $35 \cdot 3$ & $4 \cdot 7$ & $\mathrm{p} 21882$ \\
\hline $\mathrm{PdhC}$ & $\begin{array}{l}\text { Dihydrolipoamide } S \text {-acetyltransferase } \\
\text { (E2 component of pyruvate } \\
\text { dehydrogenase complex) (EC } \\
2.3 .1 .12 \text { ) }\end{array}$ & AFEFKLPDIG EGIHEGEIVK WE & 61 & $5 \cdot 3$ & $47 \cdot 4$ & $5 \cdot 0$ & p21883 \\
\hline PdhD & $\begin{array}{l}\text { Dihydrolipoamide dehydrogenase (E3 } \\
\text { component of pyruvate dehydrogenase } \\
\text { complex }\rangle \text { (EC 1.8.1.4) }\end{array}$ & VVGDFPIETD TLVIGAGPGG YVAAI & 59 & $5 \cdot 3$ & $49 \cdot 7$ & $5 \cdot 0$ & $\mathrm{p} 21880$ \\
\hline \multicolumn{8}{|c|}{ Nucleotide synthesis } \\
\hline PurA & $\begin{array}{l}\text { Adenylosuccinate synthase (EC } \\
6.3 .4 .4)\end{array}$ & SSVVVVGTQW GDEGK & 48 & $5 \cdot 8$ & $47 \cdot 9$ & $5 \cdot 7$ & p29726 \\
\hline PurH & $\begin{array}{l}\text { Phosphoribosylaminoimidazole- } \\
\text { carboxamide formyltransferase (EC } \\
2.1 .2 .3 \text { ) } \\
\text { IMP cyclohydrolase (EC } 3.5 .4 .10 \text { ) }\end{array}$ & TIKRALISVS DKT & 54 & $5 \cdot 6$ & $56 \cdot 1$ & $5 \cdot 3$ & p12048 \\
\hline \multicolumn{8}{|c|}{ Translation } \\
\hline EF-TuH & Elongation factor EF-Tu & MFRKLLDYAE AGDNIGALLR GVSRGGIQRG Q & 47 & $5 \cdot 3$ & $43 \cdot 6$ & $4 \cdot 8$ & p33166 \\
\hline EF-Ts & $\begin{array}{l}\text { Elongation factor EF-Ts } \\
\qquad \begin{array}{l}\mathrm{N} \text { terminus alignment to: } \quad \text { E. coli } \\
\text { Galdieria sulphuraria }\end{array}\end{array}$ & $\begin{array}{l}\text { AITAQQVKEL REKTGAGMMD XKKALTET } \\
\text { ITASLVKEL RERTGAGMD CKKALTE } \\
\text { ISAQLVKEL REITGAGMD CKKALRES }\end{array}$ & 34 & $5 \cdot 5$ & $\mathrm{NA}$ & $\mathrm{NA}$ & p 80700 \\
\hline $\begin{array}{l}\text { TCA cycl } \\
\text { CitC }\end{array}$ & $\begin{array}{l}\text { Isocitrate dehydrogenase }\left(\mathrm{NADP}^{+}\right) \\
(\mathrm{EC} 1.1 .1 .42)\end{array}$ & AQGEKITVSN GVLNVPNNPI IPFI & 42 & $5 \cdot 3$ & $46 \cdot 4$ & $5 \cdot 0$ & p39126 \\
\hline \multicolumn{8}{|c|}{$\begin{array}{l}\text { Pentose phosphate } \\
\text { cycle }\end{array}$} \\
\hline GntZ II & $\begin{array}{l}\text { Phosphogluconate dehydrogenase II } \\
\text { (EC } 1.1 .1 .44 \text { ) } \\
\text { alignment to: B. subtilis }\end{array}$ & $\begin{array}{l}\text { SXQQJGVIGW AVM } \\
\text { MFNSIGVIGL GVM }\end{array}$ & 44 & $5 \cdot 6$ & $\mathrm{NA}$ & $\mathrm{NA}$ & \\
\hline \multicolumn{8}{|c|}{$\begin{array}{l}\text { Protein of unknown } \\
\text { function }\end{array}$} \\
\hline YxiG & $\begin{array}{l}\text { Hypothetical } 38 \cdot 0 \mathrm{kDa} \text { protein in katE } \\
3^{\prime} \text { region }\end{array}$ & KQQTTPAEQK SLQRKKPXFR ADQVG & 44 & $5 \cdot 5$ & $38 \cdot 0$ & $5 \cdot 4$ & $\mathrm{p} 42318$ \\
\hline \multicolumn{8}{|c|}{$\begin{array}{l}\text { Proteins not found in } \\
\text { the databases }\end{array}$} \\
\hline Veg2 & No homology & SVKWEKQEGN EGVLTVEVDA ETFK & 60 & $4 \cdot 9$ & $\mathrm{NA}$ & $\mathrm{NA}$ & p80698 \\
\hline Veg6 & No homology & LGTGLGVDQN & 61 & $5 \cdot 5$ & $\mathrm{NA}$ & NA & p80699 \\
\hline
\end{tabular}

" Comparisons with homologous proteins of other bacteria are given for Pgk and EF-Ts (bold, identical amino acids; underlined, conserved substitutions).

t The isoelectric point and molecular mass of the proteins were calculated with the SWISS-PROT ProtParams tool. NA, not available.

$\ddagger$ The molecular mass of the proteins was estimated using molecular mass standards.

$\$$ The isoelectric point of the proteins was estimated using a standard curve obtained from isoelectric points calculated from the sequence data.

|) Since the $\mathrm{N}$ terminus of EF-Tu was blocked, the protein was cleaved with $\mathrm{CNBr}$ and the sequence of an internal fragment is given. 
transferred onto a PVDF membrane, stained and sequenced using an Applied Biosystems A473a Protein Sequencer. For cleavage with cyanogen bromide (CNBr), gel pieces were shaken overnight in $0.75 \mathrm{M} \mathrm{CNBr}$ dissolved in $80 \%$ formic acid. After washing with $80 \%$ formic acid, evaporation and neutralization, the peptides were dissolved in sample buffer and separated on a polyacrylamide gel according to Schaegger \& Von Jagow (1987). The peptides were transferred onto a PVDF membrane, stained and sequenced as described above.

Computer-aided analysis of 2-D gels. The dried 2-D gels were exposed to phosphor screens (Molecular Dynamics Storage Phosphor Screen $20 \times 25 \mathrm{~cm}$ ) for $24 \mathrm{~h}$ and scanned with a PhosphorImager SI (Molecular Dynamics) at a resolution of $200 \mu \mathrm{m}$. The resulting digitized gel images were analysed using the PDQuest package version 5.0 for quantitative analysis of 2-D gels (for a more detailed description, see the user's guide of PDQuest version 5.0). The relative synthesis rate of every spot was calculated and expressed as:

$\left(\frac{\text { Radioactivity of individual spot }}{\text { Radioactivity of whole gel }} \times 100\right) \%$

All experiments were performed at least twice and the SD was $20 \%$.

Computer-accessible protein data. All the protein data described in this communication can be accessed in 'Sub2Dthe 2-D protein index of Bacillus subtilis' via the World Wide Web using a WWW browser like Mosaic or Netscape under the URL http://www.uni-greifswald.de/ aghecker/ index.html

\section{RESULTS AND DISCUSSION}

\section{Identification of vegetative proteins on 2-D gels}

In the past we have focused on the investigation of the stress response of $B$. subtilis. Most of the stress proteins are synthesized at very low rates during growth and are therefore barely detectable during growth. In the course of our work we have realized that a number of prominent proteins from extracts of exponentially growing cells continue to be synthesized at rather high, albeit reduced rates after various stresses. For this reason these proteins could serve as ideal marker spots (reference points) in the construction of a $2-\mathrm{D}$ protein index of B. subtilis. Since these proteins are intensively synthesized during growth (Fig. 1) and their synthesis drops during the exposure to a number of different stresses, it was reasonable to assume that they represent enzymes which perform house-keeping functions in the cell. Twenty-three protein spots were selected, cut from preparative 2-D gels and their $\mathrm{N}$-terminal sequence determined (Fig. 1, Table 1). For 18 of the 23 proteins a comparison with the databases resulted in the unambiguous identification of the spots because the $\mathrm{N}$ terminal amino acid sequences determined matched the sequences of proteins for which the genes have already been sequenced in B. subtilis. The $\mathrm{N}$-terminal sequences of enolase (Eno) and glyceraldehyde-3-phosphate dehydrogenase (Gap) have already been determined (Miller et al., 1991).

For one of the spots the $\mathrm{N}$-terminus was blocked, but the determination of the sequence of an internal peptide led to the identification of elongation factor EF-Tu of $B$.

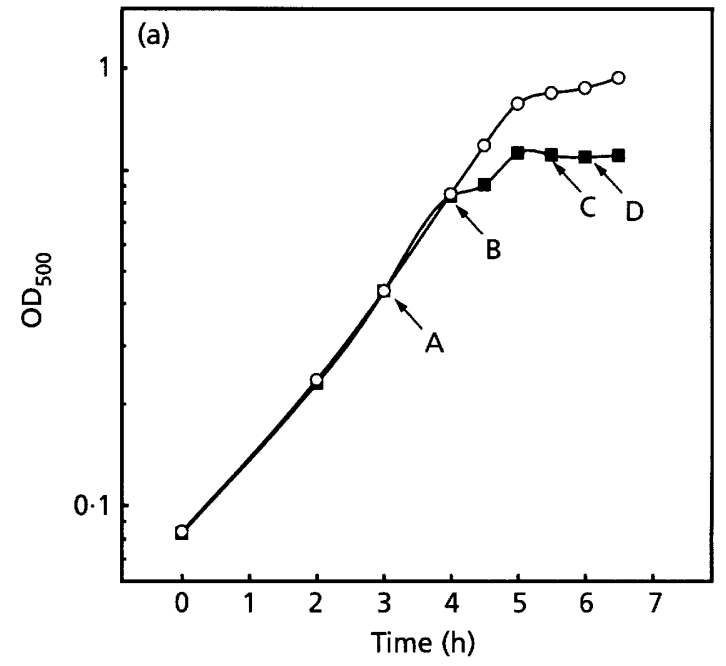

Fig. 2. Synthesis of selected vegetative proteins of $B$. subtilis during growth and after glucose starvation. (a) $B$. subtilis strain IS58 was grown in a synthetic medium with growth-limiting amounts of glucose $(0,0.20 \% ; \square, 0.05 \%)$. At the time points labelled A, B, C and D, aliquots of the culture were labelled with L-[ $\left.{ }^{35} \mathrm{~S}\right]$ methionine for $3 \mathrm{~min}$. (b) Autoradiograms of crude protein extracts from cells labelled during growth (Sample A) or during glucose starvation (Sample D).

subtilis. For two of the spots the sequences of the genes encoding the proteins have not been determined yet. The high degree of identity with proteins from E. coli and other bacteria, however, argued that the protein spots represented the elongation factor EF-Ts and phosphoglycerate kinase (Pgk) of $B$. subtilis. The N-terminal sequences of two spots (Veg2 and Veg6) did not display any significant similarities to proteins in the databases. The proteins identified so far perform functions in glycolysis and the pentose phosphate cycle, the TCA cycle, amino acid and nucleotide biosynthesis and in translation (Table 1).

\section{Effects of glucose starvation or heat shock and salt stress on the synthesis of the proteins identified}

Visual interpretation of the autoradiograms of 2-D gels indicated that the vegetative proteins examined in this study were synthesized at a reduced rate after exposure to growth-restricting conditions (Fig. 2b, Table 2). Therefore, we used computer-aided analysis of the 2-D gels to investigate the response of those genes to stress and starvation. During glucose starvation the relative synthesis rate of most vegetative proteins, including the proteins identified, decreased (Fig. 2b, 3), correlating with their function in the cell. Upon entry into the stationary phase, the synthesis of enzymes involved in the biosynthesis of building blocks, like amino acids or nucleotides, was shut down. This is shown for 2-dehydro-3-deoxyphosphoheptonate aldolase/ chorismate mutase (AroA), glycine hydroxymethyltransferase (GlyA), ketol-acid reductoisomerase (IlvC), threonine synthase ( $\mathrm{ThrC}$ ), homoserine dehydrogenase (Hom), phosphoglycerate dehydrogenase (SerA), glu- 
Sample A

(b)

8

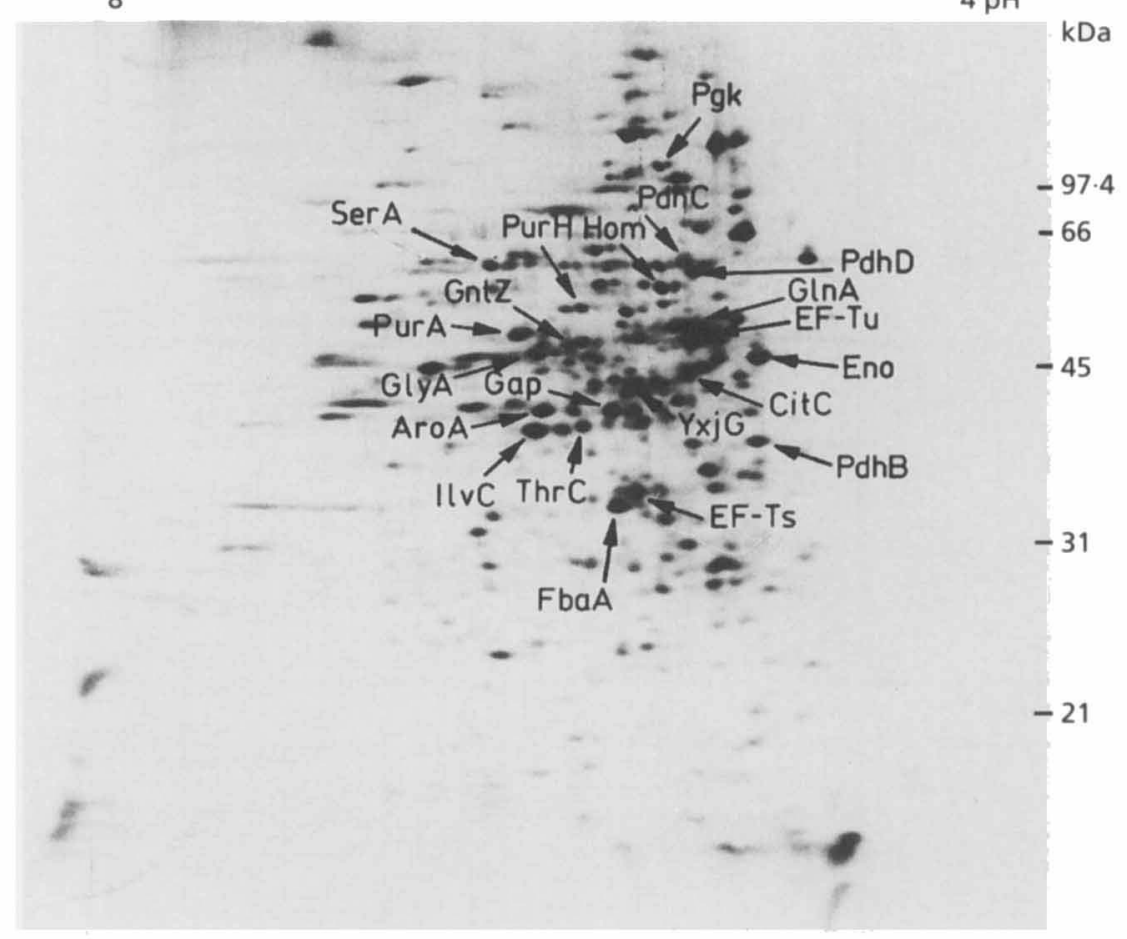

Sample D

8

$4 \mathrm{pH}$

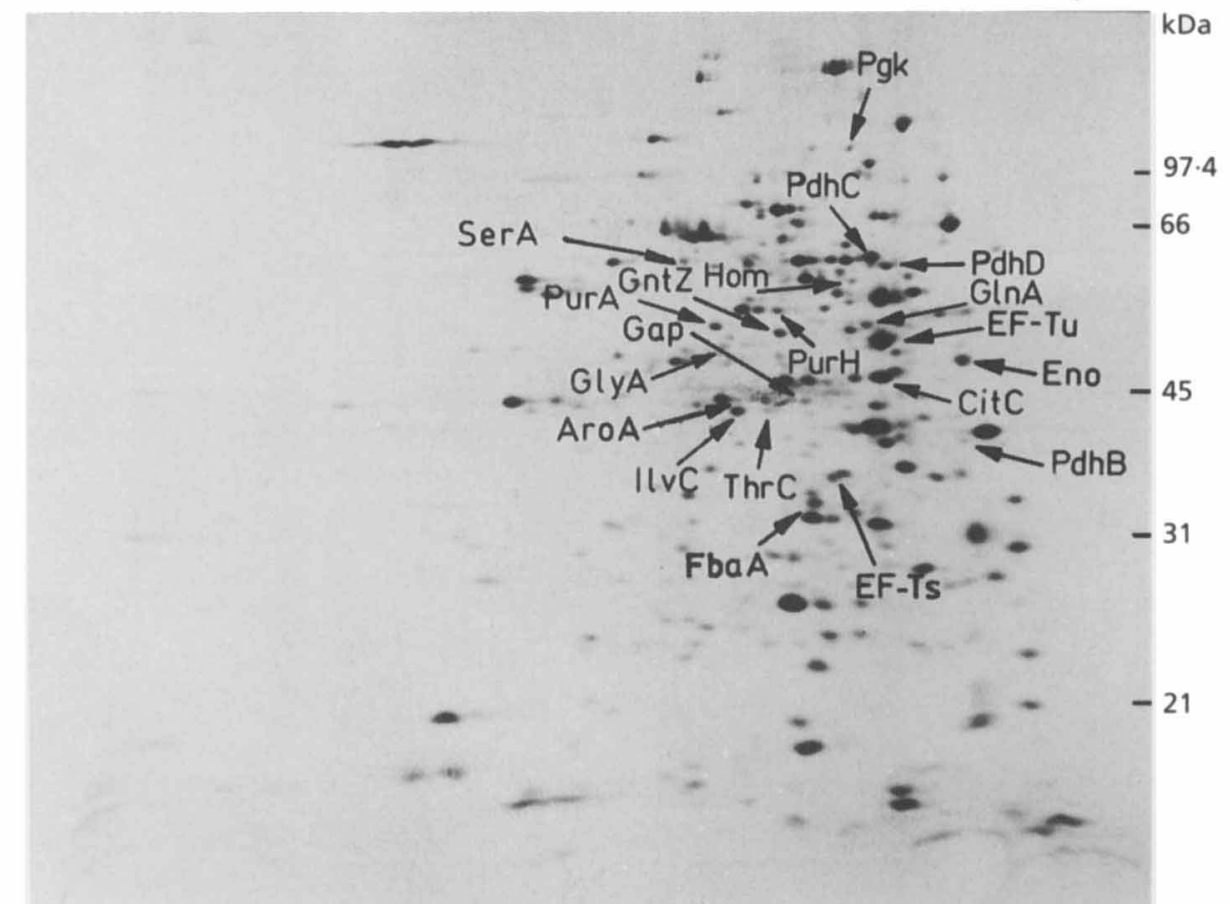

Fig. 2. For legend see facing page. 
Amino acid metabolism
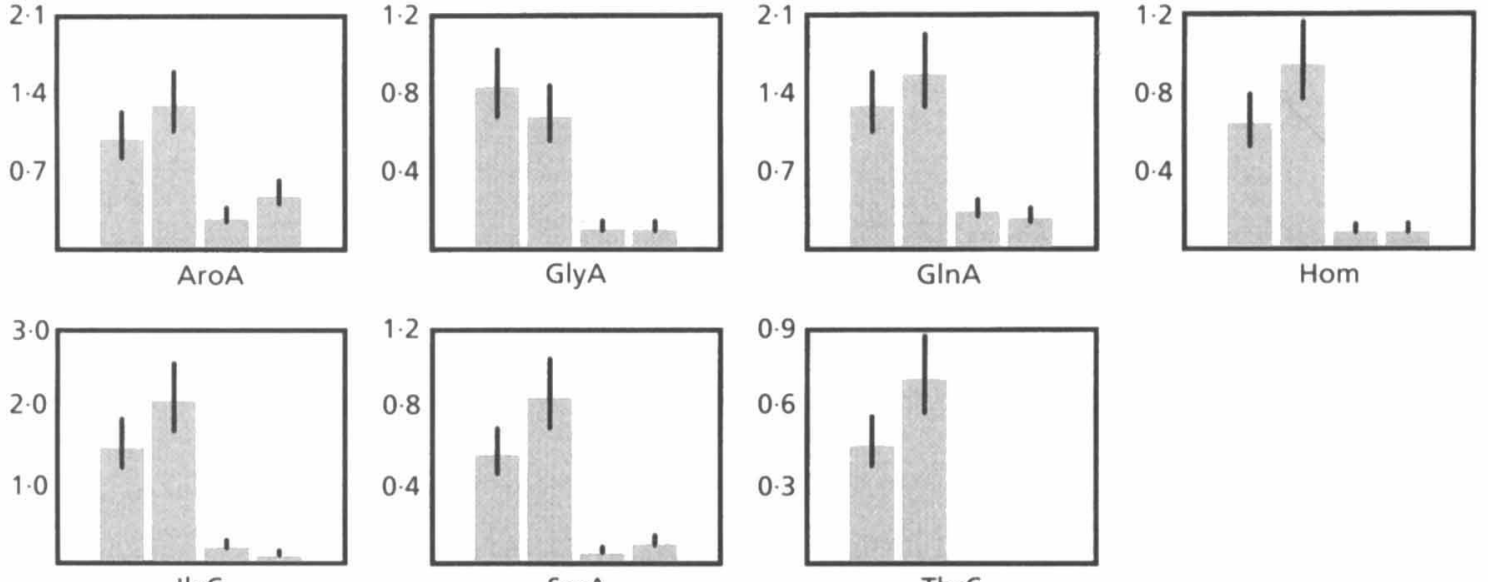

Hom

Glycolysis

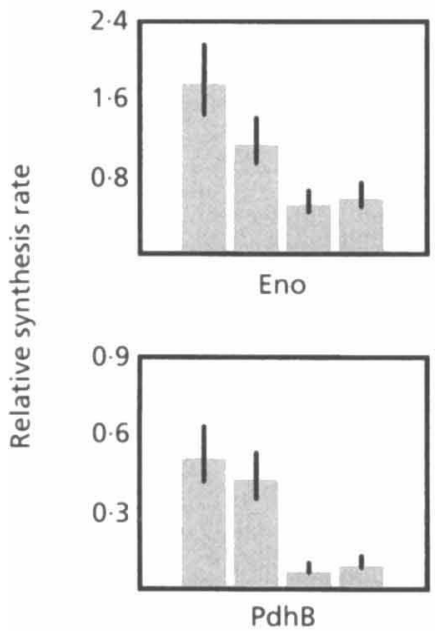

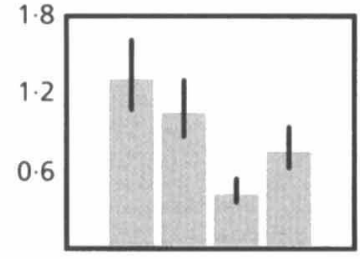

FbaA

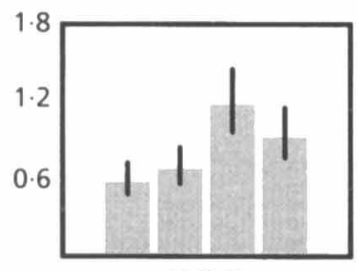

PdhC

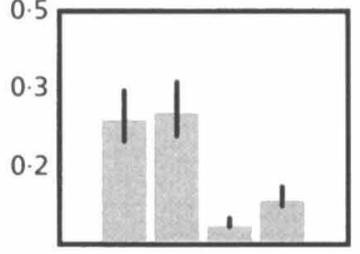

Pgk

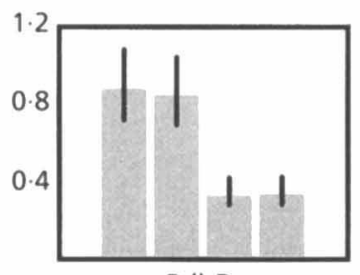

PdhD

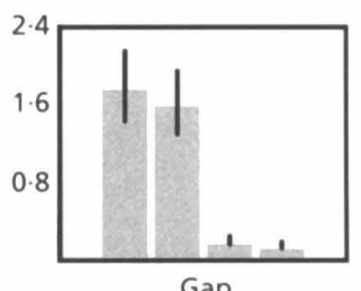

Gap

Nucleotide synthesis

Translation

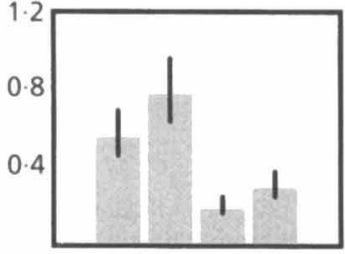

PurA

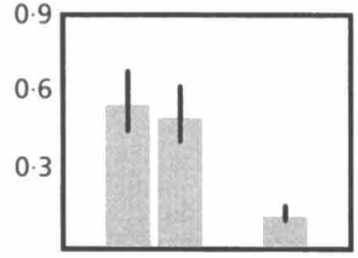

PurH

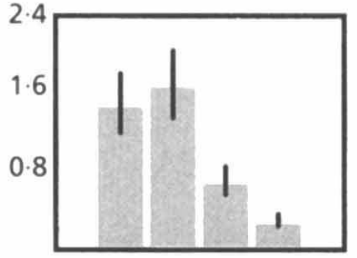

EFTs

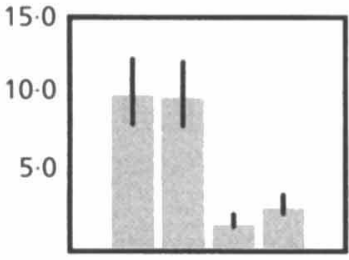

EFTu

TCA cycle

Pentose phosphate cycle

Unknown
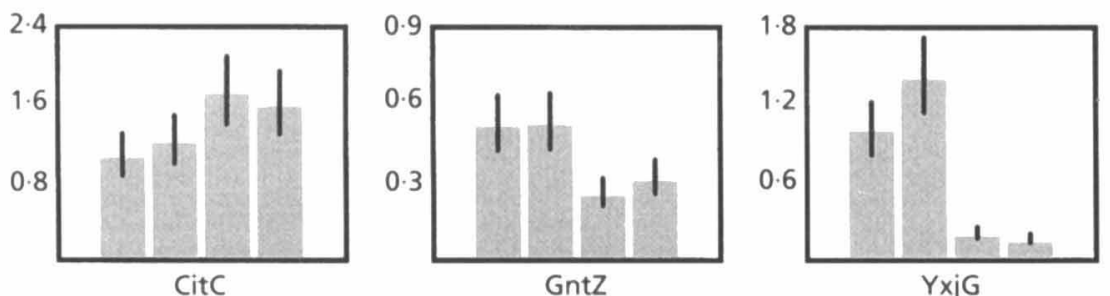
Table 2. Relative synthesis rates of vegetative proteins during exponential growth and during heat shock

B. subtilis IS58 was cultivated in a synthetic medium and labelled during growth or after exposure to heat shock with $\mathrm{L}-\left[{ }^{35} \mathrm{~S}\right]$ methionine for $3 \mathrm{~min}$. The samples were processed as described in Methods and in the legend to Fig. 3. The relative synthesis rates of the proteins are given.

\begin{tabular}{|c|c|c|c|c|}
\hline \multirow[t]{2}{*}{ Protein } & \multicolumn{4}{|c|}{ Relative synthesis rate } \\
\hline & Control & $5 \mathrm{~min}$ & $10 \mathrm{~min}$ & $20 \mathrm{~min}$ \\
\hline \multicolumn{5}{|c|}{$\begin{array}{l}\text { Amino acid } \\
\text { metabolism }\end{array}$} \\
\hline AroA & 1.7 & $0 \cdot 3$ & $0 \cdot 1$ & $0 \cdot 3$ \\
\hline GlyA & $1 \cdot 0$ & $0 \cdot 2$ & $0 \cdot 2$ & $0 \cdot 2$ \\
\hline$G \ln A$ & $1 \cdot 9$ & 0.5 & $0 \cdot 3$ & $0 \cdot 9$ \\
\hline Hom & $0 \cdot 8$ & $0 \cdot 2$ & $0 \cdot 1$ & $0 \cdot 6$ \\
\hline $\mathrm{IlvC}$ & $2 \cdot 2$ & $0 \cdot 3$ & $0 \cdot 2$ & $0 \cdot 3$ \\
\hline SerA & $0 \cdot 8$ & $0 \cdot 1$ & $0 \cdot 1$ & $0 \cdot 3$ \\
\hline ThrC & $0 \cdot 7$ & $0 \cdot 1$ & $0 \cdot 1$ & $0 \cdot 3$ \\
\hline \multicolumn{5}{|c|}{ Glycolysis } \\
\hline Eno & $2 \cdot 0$ & $1 \cdot 3$ & $0 \cdot 9$ & $1 \cdot 6$ \\
\hline $\mathrm{FbaA}$ & $1 \cdot 0$ & $0 \cdot 1$ & & $0 \cdot 3$ \\
\hline Pgk & $0 \cdot 3$ & $0 \cdot 1$ & $0 \cdot 1$ & $0 \cdot 2$ \\
\hline Gap & $2 \cdot 7$ & $1 \cdot 3$ & $1 \cdot 6$ & 1.7 \\
\hline PdhB & $0 \cdot 7$ & $0 \cdot 3$ & $0 \cdot 3$ & $0 \cdot 3$ \\
\hline PdhC & 0.7 & $0 \cdot 5$ & $0 \cdot 4$ & $0 \cdot 8$ \\
\hline PdhD & $1 \cdot 1$ & 0.7 & $0 \cdot 5$ & 0.7 \\
\hline \multicolumn{5}{|c|}{ Nucleotide synthesis } \\
\hline PurA & $0 \cdot 6$ & $0 \cdot 1$ & & $0 \cdot 1$ \\
\hline PurH & $0 \cdot 4$ & $0 \cdot 1$ & $0 \cdot 1$ & $0 \cdot 1$ \\
\hline \multicolumn{5}{|c|}{ TCA cycle } \\
\hline CitC & $1 \cdot 3$ & $0 \cdot 5$ & $0 \cdot 5$ & $0 \cdot 9$ \\
\hline \multicolumn{5}{|c|}{ Translation } \\
\hline EF-Ts & 1.6 & $0 \cdot 3$ & $0 \cdot 1$ & $0 \cdot 5$ \\
\hline $\mathrm{EF}-\mathrm{Tu}$ & $10 \cdot 7$ & $4 \cdot 8$ & $2 \cdot 9$ & 6.5 \\
\hline \multicolumn{5}{|c|}{$\begin{array}{l}\text { Pentose phosphate } \\
\text { cycle }\end{array}$} \\
\hline GntZ II & $0 \cdot 5$ & $0 \cdot 2$ & $0 \cdot 2$ & $0 \cdot 3$ \\
\hline \multicolumn{5}{|c|}{ Unknown function } \\
\hline YxjG & $1 \cdot 2$ & $0 \cdot 3$ & $0 \cdot 3$ & $0 \cdot 4$ \\
\hline
\end{tabular}

tamine synthetase $(\mathrm{G} \ln \mathrm{A})$, adenylosuccinate synthase (PurA) and phosphoribosylaminoimidazolecarboxamide formyltransferase/IMP cyclohydrolase (PurH) (Fig. 2b).

The exhaustion of glucose also reduced the synthesis of the elongation factors EF-Ts and EF-Tu. In E. coli the expression of EF-Tu is subject to the stringent response (Cashel \& Rudd, 1987) and in this respect it might be interesting to ask if the stringent response is involved in this down regulation in $B$. subtilis.

The enzymes involved in glycolysis, such as enolase (Eno), glyceraldehyde-3-phosphate dehydrogenase (Gap), phosphoglycerate kinase (Pgk), fructose-bisphosphate aldolase $(\mathrm{FbaA})$, the pyruvate dehydrogenase complex E1 component (PdhB) and the dihydrolipoamide dehydrogenase component $(\mathrm{PdhD})$ were produced at a reduced level during stationary phase provoked by glucose starvation. In contrast to these glycolytic enzymes, the synthesis of isocitrate dehydrogenase $(\mathrm{CitC})$ involved in the TCA cycle was stimulated during glucose starvation. It has been reported that enzymes of the TCA pathway are repressed in cells supplied with an excess of glucose because they are needed at low level if glycolysis is high (Hanson \& Cox, 1967). After exhaustion of glucose, glycolysis is unable to generate enough energy and the TCA cycle plays the key role in energy production (Sonenshein, 1989). This regulation of CitC was reflected on the 2-D gels (Fig. 2b).

During heat stress the relative synthesis rate of proteins involved in glycolysis, synthesis of amino acids and nucleotides, translation and the TCA cycle was reduced to approximately $50-10 \%$ of the pre-shift level (Table 2 ). This rather strong reduction in the synthesis of vegetative proteins might partially be caused by the simultaneous strong induction of at least three groups of heat-inducible proteins (see Bernhardt et al., 1997, and Hecker et al., 1996, for review). This assumption is supported by the analysis of a $\sigma^{\mathrm{B}}$ mutant strain which failed to induce the majority of general stress proteins upon heat shock. In this mutant strain the relative synthesis rate of vegetative proteins after heat shock was less reduced than in the wild-type (data not shown).

A similar reduction in the synthesis of vegetative proteins was observed after cells had been exposed to salt stress (data not shown).

Due to their high level of synthesis the proteins identified in this report constitute useful marker spots for the construction of the $2-\mathrm{D}$ protein index of $B$. subtilis. In the next step we and others will extend the index of vegetative proteins and proteins induced during special cultivation conditions will be added (Graumann et al., 1996). In the accompanying paper (Bernhardt et al., 1997) this is demonstrated for general and specific stress proteins of $B$. subtilis.

\section{ACKNOWLEDGEMENTS}

This work was supported by grants from the Deutsche Forschungsgemeinschaft, the Fonds der Chemischen Industrie and the BMBF (03109290) to M.H. We thank Eva Uhlemann and Karin Binder for excellent technical assistance in electro-

Fig. 3. Relative synthesis rates of vegetative proteins during growth and glucose starvation. Crude protein extracts were prepared, separated by 2-D protein gel electrophoresis and quantified as described in Methods. The bars (from left to right) display the relative synthesis rates of the proteins at time points $A, B, C$ and D marked in Fig. 2(a). The error bars represent the SD calculated from five independent gels for the control and two independent gels for the glucose starvation samples. 
phoresis techniques and Gertrud Schittek and Sabine Schade for continuous support in the preparation of the 2-D gel photographs.

\section{REFERENCES}

Antelmann, H., Bernhardt, J., Schmid, R. \& Hecker M. (1995). A gene at 333 degrees on the Bacillus subtilis chromosome encodes the newly identified $\sigma^{\mathrm{B}}$-dependent general stress protein GspA. $J$ Bacteriol 177, 3540-3545.

Bernhardt, J., Völker, U., Völker, A., Antelmann, H., Schmid, R., Mach, H. \& Hecker, M. (1997). Specific and general stress proteins in Bacillus subtilis - a two-dimensional protein electrophoresis study. Microbiology, 143, 000-000.

Cashel, M. \& Rudd, K. (1987). The stringent response. In Escherichia coli and Salmonella typhimurium-Cellular and Molecular Biology, pp. 1410-1438. Edited by F. C. Neidhardt, J. L. Ingraham, K. Brooks-Low, B. Magasanik, M. Schaechter \& H. E. Umbarger. Washington, DC: American Society for Microbiology.

Corbett, J. M., Wheeler, C. H., Baker, C. S., Yacoub, M. H. \& Dunn, M. J. (1994). The human myocardial two-dimensional gel protein database: Update 1994. Electrophoresis 15, 1459-1465.

Devine, K. M. (1995). The Bacillus subtilis genome project: aims and progress. Trends Biotechnol 13, 210-216.

Fleischmann R. D. and others (1995). Whole-genome random sequencing and assembly of Haemophilus influenzae Rd. Science 269, 496-512.

Fraser C. M. and others (1995). The minimal gene complement of Mycoplasma genitalium. Science 270, 397-403.

Garrels, J. I. (1995). YPD - a database for the proteins of Saccharomyces cerevisiae. Nucleic Acids Res 24, 46-49.

Golaz, O., Hughes, G. J., Frutiger, S., Paquet, N., Bairoch, A., Pasquali, C., Sanchez, J. C., Tissot, J. D., Appel, R. D. \& Walzer, C. (1993). Plasma and red blood cell protein maps: update 1993. Electrophoresis 14, 1223-1231.

Graumann, P., Schröder K., Schmid, R. \& Marahiel, M. A. (1996). Cold shock stress-induced proteins in Bacillus subtilis. J Bacteriol 178, 4611-4619.

Hanson, R. S. \& Cox, D. P. (1967). Effects of different nutritional conditions on the synthesis of tricarboxylic acid cycle enzymes. $J$ Bacteriol 93, 1777-1787.

Hecker, M., Schumann, W. \& Völker, U. (1996). Heat-shock and general stress response in Bacillus subtilis. Mol Microbiol 19, $417-428$.

Hughes, G. J., Frutiger, S., Paquet, N., Pasquali, C., Sanchez, J. C., Tissot, J. D., Bairoch, A., Appel, R. D. \& Hochstrasser, D. F. (1993).
Human liver protein map: update 1993. Electrophoresis 14, $1216-1222$.

Kunst, F. \& Devine, K. (1991). The project of sequencing the entire Bacillus subtilis genome. Res Microbiol 142, 905-912.

Lemkin, P. F., Orr, G. A., Goldstein, M. P., Creed, G. J., Myrick, J. E. \& Merril, C. R. (1995). The Protein Disease Database of human body fluids: II. Computer methods and data issues. Appl Theor Electrophor 5, 55-72.

Merril, C. R., Goldstein, M. P., Myrick, J. E., Creed, G. J. \& Lemkin, P. F. (1995). The Protein Disease Database of human body fluids: I. Rationale for the development of this database. Appl Theor Electrophor 5, 49-54.

Miller, B. S., Kennedy, T. E. \& Streips, U. N. (1991). Molecular characterisation of specific heat shock proteins in Bacillus subtilis. Curr Microbiol 22, 231-236.

Rider, M. H., Puype, M., VanDamme, J., Gevaert, K., DeBoeck, S. D'Alayer, J., Rasmussen, H. H., Celis, J. H. \& Vanderkerckhove, J. (1995). An agarose-based gel-concentration system for microsequence and mass spectrometric characterisation of proteins previously purified in polyacrylamide gels starting at low picomole levels. Eur J Biochem 230, 258-266.

Schaegger, H. \& Von Jagow, G. (1987). Tricine-sodiumdodecylsulfate-polyacrylamide gel electrophoresis for the separation of proteins in the range from $1-100 \mathrm{kDa}$. Anal Biochem $166,368-379$.

Smith, L., Paress, P., Cabane, K. \& Dubnau, E. (1980). Genetics and physiology of the rel system of Bacillus subtilis. Mol Gen Genet 179, 271-279.

Sonenshein, A. (1989). Metabolic regulation of sporulation and other stationary phase phenomena. In Regulation of Prokaryotic Development, pp. 109-130. Edited by Issar Smith, Ralph A. Slepecky \& Peter Setlow. Washington, DC: American Society for Microbiology.

Stülke, J., Hanschke, R. \& Hecker, M. (1993). Temporal activation of $\beta$-glucanase synthesis in Bacillus subtilis is mediated by the GTP pool. J Gen Microbiol 139, 2041-2045.

VanBogelen, R. A., Sankar, P., Clark, R. L., Bogan, J. A. \& Neidhardt, F. C. (1992). The Gene-Protein Database of Escherichia coli-Edition 5. Electrophoresis 13, 1014-1054.

Völker, U., Engelmann, S., Maul, B., Riethdorf, S., Völker, A., Schmid, R., Mach, H. \& Hecker, M. (1994). Analysis of the induction of general stress proteins of Bacillus subtilis. Microbiology 140, 741-752.

Received 29 May 1996; revised 27 August 1996; accepted 8 October 1996. 